\title{
Developing a Pop-Up Book for Written Descriptive Text for Senior High school Students
}

\author{
Irma Khoirur Rosyida ${ }^{1}$, Testiana Deni Wijayatiningsih ${ }^{3}$, Dodi Mulyadi ${ }^{3}$ \\ \{irmakhoirurrosyida@gmail.com ${ }^{1}$ \} \\ Universitas Muhammadiyah Semarang, Indonesia ${ }^{1,2,3}$
}

\begin{abstract}
Most students get bored and unenthusiastic in mastering English descriptive text using media textbook and worksheet because they consist of one dimension and the paper on every page was not colorful and interesting. Moreover, media and material in learning English descriptive text the teachers used were limited. This research used research and development method from Sugiyono [1] adopted from Borg \& Gall. The instruments of this research were the assessment rubrics of learning media from the experts, a questionnaire about students' responses toward Pop-Up Book for Descriptive Text, and test to find out the effectiveness of Pop-Up Book analysis. The experts' assessment results showed that PopUp Book scored 4.6 in terms of media and 4.5 in terms of the subject matter. The score showed that both media and material from the Pop-Up Book for Descriptive Text were categorized as very good criteria. The results of the questionnaire about students' response to the Pop-Up Book for Descriptive Text was 4.24 on small-scale product trial and 4.5 on a large-scale product trial with very good criteria. Both results on students' response questionnaires showed that the Pop-Up Book for Descriptive Text gained positive responses from the students. Meanwhile, the data about Pop-Up Book for Descriptive Text effectiveness was analyzed using the T-test. The result of the T-test obtained from SPSS indicated that there was a significant influence of Pop-Up Book for Descriptive text on the average score of students' descriptive text performance. Overall, it can be concluded that the Pop-Up Book for Descriptive Text is feasible and effective to be utilized as a learning media for Senior High School students.
\end{abstract}

Keywords: Pop-Up Book, Descriptive Text, Research and Development, Senior High School

\section{Introduction}

The use of appropriate learning media in teaching learning process can influence the students' achievement in learning language. Media in learning process gives advantages to make learning more attractive, material of learning more clearly, learning methods have more variations. Media assisted teachers in the process of delivering information to the students because the media can act as a tool in the learning process and learning resources for students. Media are one of the means of communication to convey the message from the sender to the receiver. Media applied in education would be very helpful in the learning process. Media used in learning process is referred to media of learning. Rusman [2] media are considered as instructional media when they carry the message with an instructional purpose to facilitate communication. Media come from Latin and is the plural of the word "medium" which literally 
means "intermediary" is an intermediary source of the message (a source) to the receiver of the message (a receive).

In the development of the education at the present time, there are many kinds of media that can be applied in language teaching. One of them is pop-up book. Pop-up book is a book that has moving parts or have a three-dimensional element and provide a more interesting story visualization, ranging from display images that can move when the page is opened.

Pictures and big books can help the students enjoy reading. As mentioned by Harmer [3], one of the students' characteristics is that they remember better toward the real things around them than abstract ones. The use of pictures is to help the students to imagine the objects. Meanwhile, Big books are useful to develop their awareness towards reading itself. The size of the books can be suited depending on the needs of the students. One of the alternatives that combines pictures and texts in big books is a pop-up book.

In pop-up books, many pictures are given to stimulate the students' imagination and fantasy on abstract things. It also provides familiar words which students would easily understand. Well-illustrated pop-up books can help them to understand the content. Students' characteristics matched well with this medium so they can write in English enjoyable, attractive, active and creative.

Compared to common storybooks, the appearance of pop-up books is more interesting since the output of pictures is (almost) in 3D. In Cambridge advanced learner's dictionary third edition, 3D is described as an object (film or picture) which looks real and solid instead of looking like a normal flat thing. Three-dimensional object is appearing to have three dimensions (width, length, and height).

Based on pre-observation done in SMAN 15 Semarang, it showed that the English teacher still used the conventional method in teaching learning process then it influences the activeness of students. Since, students get bored and unenthusiastic in mastering English descriptive text. The teacher mostly used textbook media in their learning process, such as LKS or other textbooks. Those textbooks consist of only one dimension which mean it is ordinary used for students. I think it is not really interesting enough for students. Pop-Up Book would be a new innovation in learning English for students and teachers. If the teacher tries to apply Pop-Up Book in their learning process, I believe that it gave impact on students' interest in learning process especially English.

Based on the fact above, the objectives of the research are (1) to analyze whether the PopUp Book for descriptive text is effective in order to the experts score toward Pop-Up Book for descriptive text, (2) to analyze whether the Pop-Up Book for descriptive text is appropriate in order to students' score in learning English on descriptive text, and (3) to describe the students' response toward the Pop-Up Book for descriptive text.

Pop-Up Book was chosen because based on Dzuanda [4] explained the mean of the popup book was a book that has moving parts or has a three-dimensional element and provide a more interesting story visualization, ranging from display images that can move when the page opened, for those topics above I need developed the book "Pop-Up Book with for Descriptive Text" as a medium of learning English for in class X students of SMAN 15 Semarang. 


\section{Research Methodologies}

\subsection{Research Design}

The Research and Development study (R\&D) was a research method used to produce a particular product, and test the effectiveness of the product. Step-by-step development of the media in this study was developed from Sugiyono [1]. In this research, subject of the study was the product in a Pop-Up Book for Descriptive Text that has passed the stage of revision and had been tested in class X-Social 3 of SMAN 15 Semarang. The data from the identification of problem analyzed by qualitative descriptive analysis. The results of data response experts included in the calculation of the score table in accordance with the application criteria.

Table 1. Eligibility Criteria of Pop-Up Book

\begin{tabular}{cccc}
\hline Scale & \multicolumn{1}{c}{ Interval Score } & Average Score & Assessment Criteria \\
\hline 5 & $\bar{X}>\bar{X}+1.8 \times \mathrm{Sbi}$ & $>4.2$ & Very Good \\
4 & $\bar{X} \mathrm{i}+0.6 \times \mathrm{SBi}<\mathrm{X} \leq \bar{X} \mathrm{i}+1.8 \times \mathrm{SBi}$ & $>3.4-4.2$ & Good \\
3 & $\bar{X} \mathrm{i}-0.6 \times \mathrm{SBi}<\mathrm{X} \leq \bar{X} \mathrm{i}+1.8 \times \mathrm{SBi}$ & $>2.6-3.4$ & Quite Good \\
2 & $\bar{X} \mathrm{i}-0.6 \times \mathrm{SBi}<\mathrm{X} \leq \bar{X} \mathrm{i}-0.6 \times \mathrm{Sbi}$ & $>1.8-2.6$ & Less Good \\
1 & $\mathrm{X} \leq \bar{X} \mathrm{i}-1.8 \times \mathrm{Sbi}$ & $\leq 1.8$ & Not Good \\
\hline
\end{tabular}

Source: Widoyoko [5].

Based on the research method, the research procedures are (1) preliminary observation of learning aids that used by teachers in the classroom, (2) licensing from the school to place research as a basis in research developing pop-up book for descriptive text, and (3) preparation of research instruments including the questionnaire and design media.

\subsection{Design Media}

The development of Pop-Up Book for Descriptive Text products started with the compilation of theme, decided the topics and kind things to describe (buildings and people) like Lawang Sewu, Blenduk Church, MAJT, Sam Poo Kong, and Laksamana Cheng Ho. Then, I created the storyboard, designed on each page and added images to describe on three dimensions. The Pop-Up book product was developed using Corel Draw X4. The resulting product contained background design of storyboards, the text and images to facilitate understanding and also generate interest for students. The Pop-Up Book design of descriptive text materials is as follows:

\subsubsection{What is Descriptive Text?}

On the page of descriptive text talks about the definition of descriptive text, the social function, generic structure, and language features. 


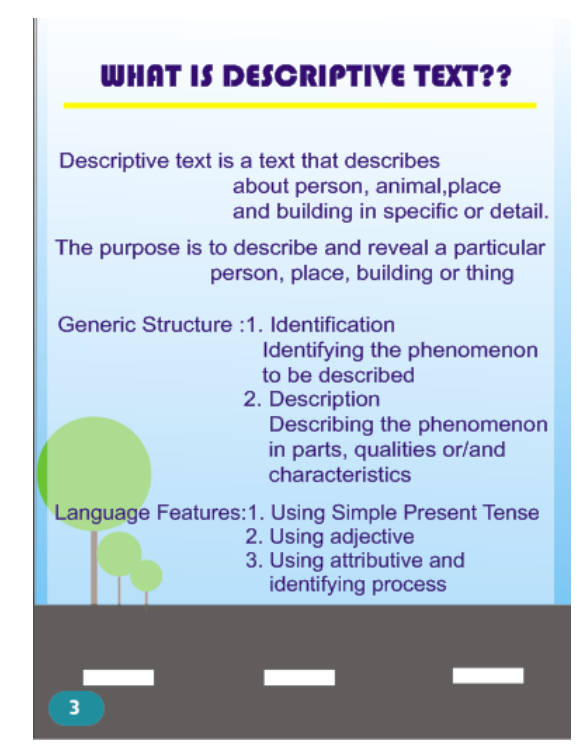

Fig. 1. What is Descriptive Text.

\subsubsection{Generic Structure}

This page talks about what is the generic structure of descriptive text. There are identification and description. Then I gave the example text of descriptive text which told about Avalokitesvara Pagoda.

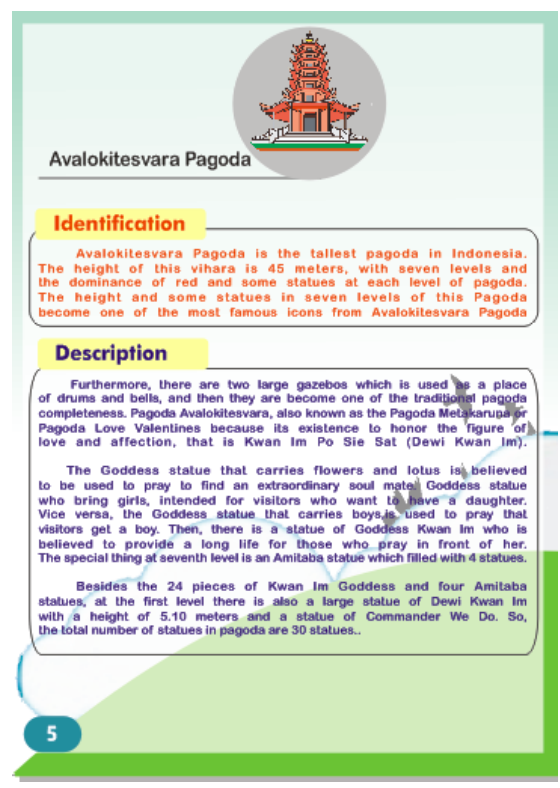

Fig. 2. The Example of the Generic Structure of Descriptive Text. 


\subsubsection{Simple Present Tense}

On this page consists of the simple way in understanding of using simple present tense and also included the pattern to arrange sentence in simple present tense. Simple present tense could be use in habits, general facts, schedules, and true in the present. The designs of this page were colorful and the font was eye catching for students.

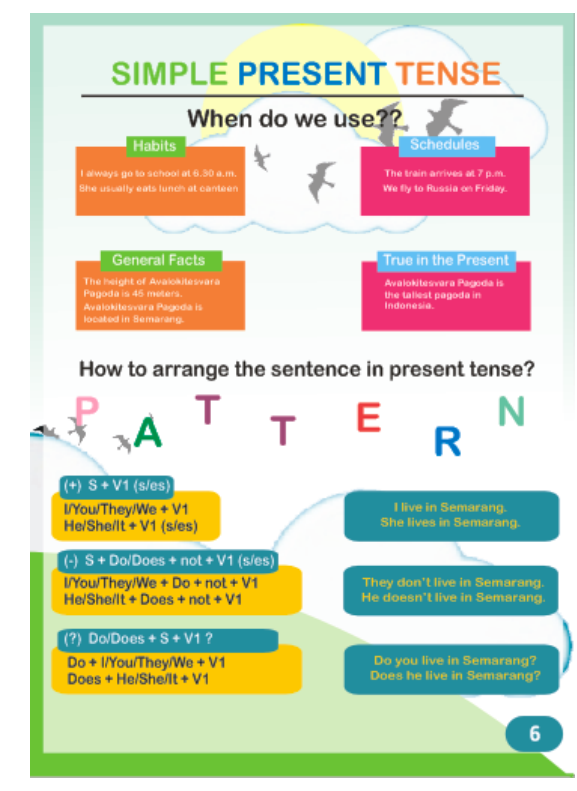

Fig. 3. Simple Present Tense.

\subsubsection{Lawang Sewu}

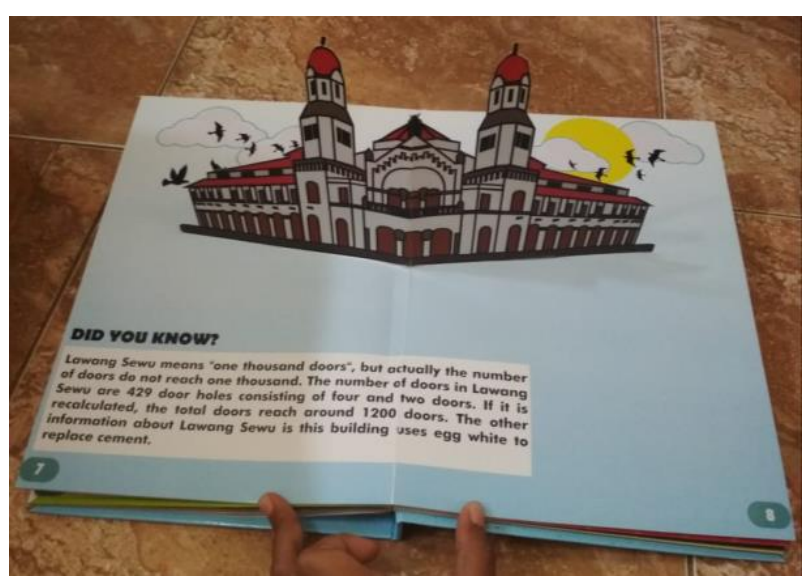

Fig. 4. Lawang Sewu. 


\section{Findings and Discussion}

\subsection{The Expert Assessment Results on Media Feasibility}

The media feasibility assessment included two aspects: the assessment by experts of media and the assessment by experts of subject matter. In media feasibility assessment was obtained from the data of feasibility test results using aspects and criteria of assessment of Pop-Up Book for Descriptive Text.

\subsubsection{Assessment Results of the Expert of Media}

The assessment of media by experts were based on an assessment sheet obtained from the feasibility test data using aspects and criteria of assessment of learning media. Pop-Up Book for Descriptive Text would be suitable to be used in learning if the score obtained from the assessment of expert of the media reach's 3.4 (Table 1). If the score obtained $<3.4$ then the media needs to be revised and then the media would be validated in the second stage. The result of the assessment of expert of the media was presented in Table 2.

Table 2. The Results of Pop-Up Book Assessment by Experts of the Media

\begin{tabular}{|c|c|c|c|c|}
\hline \multirow{2}{*}{ No. } & \multirow{2}{*}{ Aspects } & \multirow{2}{*}{ Questions } & \multicolumn{2}{|c|}{ Scoring of Validators } \\
\hline & & & I & II \\
\hline \multirow[t]{4}{*}{1} & Feasibility of & Preface & 4 & 5 \\
\hline & presentation & Student involvement & 4 & 4 \\
\hline & & Ease of use & 5 & 5 \\
\hline & & The use of language & 4 & 4 \\
\hline \multirow[t]{7}{*}{2} & $\begin{array}{l}\text { Physical } \\
\text { media }\end{array}$ & $\begin{array}{l}\text { The appropriate size of the Pop-Up } \\
\text { Book }\end{array}$ & 4 & 5 \\
\hline & & $\begin{array}{l}\text { The appropriate colors of the } \\
\text { background }\end{array}$ & 5 & 5 \\
\hline & & Color suitability used & 4 & 5 \\
\hline & & $\begin{array}{l}\text { The font type is interesting and easy to } \\
\text { read }\end{array}$ & 5 & 4 \\
\hline & & The size of font & 5 & 4 \\
\hline & & The suit cover appearance & 4 & 4 \\
\hline & & Illustration and animation & 4 & 4 \\
\hline Total & & & 4.3 & 4.45 \\
\hline \multicolumn{3}{|c|}{ The Average of Score } & \multicolumn{2}{|c|}{4.4} \\
\hline \multicolumn{3}{|c|}{ Category } & \multicolumn{2}{|c|}{ Very Good } \\
\hline
\end{tabular}

Based on Table 2, it can be seen that the value for Pop-Up Book provided by experts of the media reached a score 4.4 or I can classify it into very good category. The experts of the media gave score of two on the aspect of worthiness presentation and the physical of media, this was because in the worthiness aspects, the indicators needed to be revised and should be based on the easier in using the Pop-Up Book for students, the involvement between the book and students. While in the physical of media, contains of the appropriateness of the book. So, based on the experts of media, this book was very effective to be implemented for X-class students. 


\subsubsection{Assessment Results of the Expert of Subject Matter}

The assessment of the material on Pop-Up Book for Descriptive Text was started with the validation stage which validated if the material on the media was eligible to be used. On the other hand, the material was eligible if the score $\geq 3.4$ (Table 1). The expert of subject matter validation results is presented in Table 3 .

Table 3. The Results of Pop-Up Book for Descriptive Text by Expert of Subject Matter

\begin{tabular}{|c|c|c|c|c|}
\hline \multirow{2}{*}{ No. } & \multirow{2}{*}{ Aspects } & \multirow{2}{*}{ Questions } & \multicolumn{2}{|c|}{ Scoring of Validators } \\
\hline & & & I & II \\
\hline \multirow[t]{8}{*}{1} & The feasibility & Compatibility of material with SK and KD & 4 & 5 \\
\hline & of subject & Completeness of material & 3 & 4 \\
\hline & matter & Material truth & 4 & 5 \\
\hline & & Creating curiosity & 4 & 5 \\
\hline & & Material clarity & 4 & 4 \\
\hline & & Material sequence & 4 & 5 \\
\hline & & $\begin{array}{l}\text { The ease of understanding the contents of } \\
\text { the material in the text }\end{array}$ & 4 & 5 \\
\hline & & Material balance with practice & 3 & 4 \\
\hline \multirow[t]{3}{*}{2} & $\begin{array}{l}\text { Contextual } \\
\text { assessment }\end{array}$ & $\begin{array}{l}\text { Compatibility of material with the real } \\
\text { environment of students }\end{array}$ & 4 & 4 \\
\hline & & $\begin{array}{l}\text { The ability of students to connect the } \\
\text { knowledge they have with their application } \\
\text { in everyday life }\end{array}$ & 4 & 5 \\
\hline & & Constructivism & 4 & 5 \\
\hline \multicolumn{3}{|c|}{ Total } & 3.8 & 4.6 \\
\hline \multicolumn{3}{|c|}{ The Average of Score } & \multicolumn{2}{|c|}{4.2} \\
\hline \multicolumn{3}{|c|}{ Category } & \multicolumn{2}{|c|}{ Very Good } \\
\hline
\end{tabular}

Based on the Table 3, it can be seen that the value for Pop-Up Book for Descriptive Text provided by expert of subject matter reached a score 4.2 with very good criteria. The expert of subject matter gave a score of 5,4,3 in all aspects of the existing material sheet of Pop-Up Book for Descriptive Text can be used as a learning media in school. So, based on the experts of subject matter, this book was very effective to be implemented for X-class students.

\subsection{Students' Response about the Use of Pop-Up Book for Descriptive Text}

The revised Pop-Up Book for Descriptive Text based on the expert's assessment of first and second stage evaluations was then tested on a small-scale and large-scale product trial. I took 16 students of X-Class of Social 3 in SMAN 15 Semarang in implementation of smallscale product trials and all students of X-Class Social 3 in SMAN 15 Semarang, amounting to 36 students on large-scale product trials. The feasibility assessment on small-scale product trials was based on student response to Pop-Up Book for Descriptive Text. The results of student's responses in small-scale product trials are presented in Table 4. 
Table 4. The Result of Student Responses to Pop-Up Book for Descriptive Text in SmallScale Product Trial

\begin{tabular}{cllc}
\hline No. & Aspects & \multicolumn{1}{c}{ Indicator } & Score \\
\hline 1 & Happiness & Students are happy in using the Pop-Up Book for Descriptive Text & 4.6 \\
2 & Curiosity & Students are curious with Pop-Up Book for Descriptive Text & 4.06 \\
3 & Passion & Students are excited in using Pop-Up Book for Descriptive Text & 3.8 \\
4 & Activeness & Students are active in using Pop-Up Book for Descriptive Text & 4.06 \\
5 & Helpfulness & Pop-Up Book for Descriptive Text is helpful for students & 4.18 \\
6 & Easiness & Pop-Up Book for Descriptive Text is easy to use for students & 4.3 \\
7 & Practicality & Pop-Up Book for Descriptive Text is practical for students & 4.18 \\
8 & Interest & Pop-Up Book for Descriptive Text is interesting for students & 4.6 \\
\hline
\end{tabular}

$$
\begin{aligned}
\bar{X} & =\frac{\sum X}{n} \\
& =\frac{33.9375}{8} \\
& =4.24
\end{aligned}
$$

Based on Table 4, it can be seen that Pop-Up Book for Descriptive Text that had been developed shows a positive result. In a small-scale product trial obtained 4.24 with very good criteria. The score of responses indicated that the Pop-Up Book for Descriptive Text developed was well responded by students on small-scale product trials.

The feasibility assessment on large-scale product trials was based on students' responses to Pop-Up Book for Descriptive Text. The result of student's responses in large-scale product trials are presented in Table 5.

Table 5. The Result of Student Responses to Pop-Up Book for Descriptive Text in LargeScale Product Trial

\begin{tabular}{cllc}
\hline No. & Aspects & \multicolumn{1}{c}{ Indicator } & Score \\
\hline 1 & Happiness & Students are happy in using the Pop-Up Book for Descriptive Text & 4.6 \\
2 & Curiosity & Students are curious with Pop-Up Book for Descriptive Text & 4.3 \\
3 & Passion & Students are excited in using Pop-Up Book for Descriptive Text & 4.25 \\
4 & Activeness & Students toward Pop-Up Book for Descriptive Text & 4.3 \\
5 & Helpfulness & Pop-Up Book for Descriptive Text is helpful for students & 4.3 \\
6 & Easiness & Pop-Up Book for Descriptive Text is easy to use for students & 4.6 \\
7 & Practicality & Pop-Up Book for Descriptive Text is practical for students & 4.5 \\
8 & Interest & Pop-Up Book for Descriptive Text is interesting for students & 4.8 \\
\hline
\end{tabular}

$$
\begin{aligned}
\bar{X} & =\frac{\sum X}{n} \\
& =\frac{35.889}{8} \\
& =4.5
\end{aligned}
$$


Based on Table 5 indicates that students in large-scale product trials had given a good response to aspects of the use of Pop-Up Book for Descriptive Text. In a large-scale product trials obtained a score of 4.5 with very good criteria. In large-scale experiments the learning process is in accordance with design of learning that I had made. The learning process was done to obtain students' responses and the effectiveness experienced by students on their learning outcomes in large-scale product trials. So, based on the response of students in small- and largescale trials, this book was very effective to be implemented for X-class students.

\subsection{The Effectiveness of Pop-Up Book for Descriptive Text}

The effectiveness of Pop-Up Book for Descriptive Text was analyzed by using SPSS. The result of SPSS analysis showed that the value of $t_{\text {count }}$ on the small-scale trial sheet was 6.325 with the significance 0.000 . This means that the value of $t_{\text {count }}$ significance $(p=0.000<0.005)$. Moreover, on the large-scale trial sheet was 10.186 with the significance 0.000 . This also means that the value of $\mathrm{t}_{\text {count }}$ significance $(\mathrm{p}=0.000<0.005)$. The analysis was conducted to determine the effect of a Pop-Up Book for Descriptive Text on the results of students' scores in writing descriptive text. The results after analyzed indicates that there is an influence of Pop-Up Book for Descriptive Text on the average score of X-Class students of Social 3 in learning descriptive text. The effectiveness of Pop-Up Book for Descriptive Text could be seen from the assessment by the experts. The assessment results of the experts were taken based on the media assessment guidelines already provided in the study.

\section{Conclusions}

The developed Pop-Up Book is feasible and suitable for written English descriptive text teaching. It is proven by the assessment result from the expert of the media and the expert of subject matter. The media scored 4.4 from the expert of the media assessment and 4.2 from the expert of subject matter. The student's questionnaire showed that the Pop-Up Book is effective for teaching written English descriptive text. It is proven by the result of the product trial in small-scale product trial which categorized in very good criteria with score 4.24. In addition, the media also gained positive response from students in large-scale product trial with score 4.5 which was also categorized in very good criteria.

Based on the result of the research, it is expected that media Pop-Up book for descriptive text learning can be developed by making other text genres. For instance, recount text, hortatory explanation, narrative text, and etc. Next, the development of the Pop-Up Book for Descriptive Text will be supplemented for teachers and students.

\section{References}

[1] Sugiyono, Metode Penelitian Pendidikan. Bandung: Alfabeta, 2009.

[2] P. Yuliatmojo, "Mempersiapkan Guru Pada Strategi Pembelajaran Berbasis Teknologi Informasi Dan Komunikasi," Pros. APTEKINDO, vol. 6, no. 1, 2012.

[3] J. Harmer, "How to Teach English." Pearson. England, 2010.

[4] Dzuanda, "Design Pop-Up Child Book Puppet Figures Series Gatotkaca," Institut Teknologi Sepuluh Nopember, 2011.

[5] E. P. Widoyoko, "Evaluasi program pembelajaran,” Yogyakarta: pustaka pelajar, vol. 238, 2009. 